\title{
EMBARRAS DE CHOIX - NAZWY WŁASNE JAKO ODWIECZNY PROBLEM W DYDAKTYCE TŁUMACZENIA PISEMNEGO. MIĘDZY NORMĄ A UZUSEM (NA PRZYKŁADZIE TEKSTÓW POLSKICH I ROSYJSKICH)
}

Droblemowi nazw własnych w translacji (szerzej - w komunikacji międzykulturowej) poświęcono wiele prac o charakterze teoretycznym i praktycznym. Na gruncie przekładoznawstwa rosyjskiego w sposób bodaj najbardziej usystematyzowany prezentuje to zagadnienie monografia D. Jermołowicz (2005).

Jermołowicz kładzie szczególny nacisk na wyraźne odgraniczenie dwu klas zjawisk o całkowicie odrębnym statusie, a bardzo często mylonych: $\mathrm{z}$ jednej strony ogólnych zasad, na których opiera się relacja ekwiwalencji, z drugiej zaś metod tworzenia odpowiedników onomastycznych. Zasada to kry- 
terium nadrzędne, któremu podporządkowane są wszelkie inne przesłanki determinujące wybór spośród wielu odpowiedników. Zasady te dzielą się na (Jermołowicz 2005: 167):

- uwzględniające stronę formalną (формально-ориентированные принциипь),

- uwzględniające właściwości systemowe (системно-ориентированные принцииьь),

- odwołujące się do treści pojęcia (содержательно-ориентированные принципь),

Do pierwszej grupy autor zalicza m.in. zasadę podobieństwa dźwiękowego, zasadę zachowania formy graficznej; do drugiej - zasadę eufonii, zasadę zachowania jedności (tożsamości) nazwy własnej, zasadę adaptacji nazwy do systemu gramatycznego języka docelowego, a także zasadę zachowania kolorytu narodowego (blisko egzotyzacji). W tej samej - drugiej - grupie mamy zasadę biegunowo przeciwną wobec zasady zachowania kolorytu narodowego, a mianowicie wykorzystanie zasobów „onimicznych” języka docelowego (tu z kolei analogia do udomowienia czy też naturalizacji) jak również zasadę hołdowania tradycji historycznej. I wreszcie w grupie trzeciej znajduje się zasada odwołania się do desygnatu, uwzględnienia formy wewnętrznej (motywacji, budowy słowotwórczej nazwy własnej).

$\mathrm{Z}$ zasad wynikają metody tworzenia odpowiedników (szczególny przypadek techniki tłumaczeniowej), będące zastosowaniem konkretnej zasady. Przy tym oczywiste jest, że pewnym zasadom odpowiada niekiedy kilka różnych metod (technik) - np. zasada podobieństwa fonicznego może urzeczywistnić się zarówno w transkrypcji fonetycznej (allofonicznej), jak i fonematycznej. Może zaistnieć i sytuacja odwrotna: jedna metoda może służyć realizacji dwóch odrębnych zasad (np. metoda eksplikacji pojęcia wyższego rzędu - rodzajowego - może być przykładem zasady zaadaptowania nazwy własnej do systemu gramatycznego języka docelowego lub też ilustracją zasady oddania treści pojęcia (w praktyce - wskazania na desygnat), które kryje w sobie dana nazwa własna).

Złożone relacje pomiędzy zasadami a metodami (technikami) ilustruje schemat $\mathrm{w}$ aneksie 1 . Odpowiedniki onimów, utworzone $\mathrm{z}$ zastosowaniem wyżej wymienionych metod, Jermołowicz dzieli następująco: 
EMBARRAS DE CHOIX - NAZWY WŁASNE JAKO ODWIECZNY PROBLEM W DYDAKTYCE TŁUMACZENIA PISEMNEGO...

Typologia odpowiedników nazw własnych - Jermołowicz (2005: 173, adaptacja - A.S.)

\begin{tabular}{|c|c|c|}
\hline \multicolumn{3}{|c|}{ ODPOWIEDNIKI ONIMÓW } \\
\hline PRZENIESIONE DO JEZZYKA & \multicolumn{2}{|c|}{ ODDANE W JEZZYKU DOCELOWYM } \\
\hline $\begin{array}{l}\text { - onim w postaci wyjściowej } \\
\text { - hybryda }\end{array}$ & niebędące onimami & - tłumaczenie opisowe \\
\hline & mieszane & $\begin{array}{l}\text { - tłumaczenie komentujące } \\
\text { - tłumaczenie uściślające }\end{array}$ \\
\hline & \multirow{3}{*}{ onimy } & $\begin{array}{l}\text { tradycyine: } \\
\text { - odpowiednik uznany }\end{array}$ \\
\hline & & $\begin{array}{l}\text { regularne: } \\
\text { - transkrypcja } \\
\text { - transliteracja } \\
\text { - z modyfikacją fonetyczną } \\
\text { - z modyfikacją morfologiczną }\end{array}$ \\
\hline & & $\begin{array}{l}\text { substytucje: } \\
\text { - inna postać onimu } \\
\text { - onim bliski etymologicznie } \\
\text { - kalka } \\
\text { - analogia funkcjonalna } \\
\text { - onim odległy etymologicznie } \\
\text { i słowotwórczo }\end{array}$ \\
\hline
\end{tabular}

To, co w pierwszej kolejności powinno być materiałem praktycznym do analiz $\mathrm{w}$ ramach zajęć $\mathrm{z}$ propedeutyki tłumaczenia pisemnego, to onimy regularne i tradycyjne. Zazwyczaj już na wstępie zajęć studenci zapoznają się z zasadami transliteracji i transkrypcji zgodnymi z polską normą PN-ISO 9:2000, które zastąpiły wytyczne wcześniejszej normy PN-83/N-01201. W dalszej kolejności, gdy analizujemy teksty rosyjskie pod kątem sposobów transferu onimów polskich (na tzw. trzecią kulturę rezerwujemy czas odpowiednio później nie będę jej tu omawiać), poznajemy zalecenia obowiązujące w języku rosyjskim. Kwestie te regulują stosowne normy, m.in. ГOCT (zob. Jermołowicz 2005: 308, 344-348, a także Giliariewskij, Starostin 1985: 277-281, 187-196). W przypadku zapisu nazwisk i imion w paszportach obowiązują normy zawarte w stosownych rozporządzeniach Ministerstwa Spraw Wewnętrznych Federacji Rosyjskiej (zob. aneks 2 i bibliografia http://base.garant.ru/11900742.htm).

Warto równocześnie podkreślić, że zakres stosowania transliteracji jako techniki jest raczej ograniczony - zazwyczaj zawęża się do sfery opisów kata- 
logowych, danych bibliograficznych, tekstów naukowych ${ }^{1}$. W tekstach przeznaczonych dla szerokiego kręgu odbiorców zdecydowanie dominuje transkrypcja.

Typologii tekstologicznej onimów w konfrontacji przekładowej polsko-rosyjskiej wiele uwagi poświęca W. Kulpina (m.in. 2009: 289-291), podkreślając $\mathrm{w}$ ten sposób powiązanie wyborów translatorskich z kontekstem sytuacyjnym i kulturowym². Klasyfikacja uwzględnia następujące typy tekstów, w których pojawiają się specyficzne grupy onimów:

1) teksty medialne: zawierają dużo aktualnych, w tym lokalnych i niestandardowych, także zwyczajowych nazw własnych, ponadto pojawiają się w nich nominacje wtórne (onimy lokalne występują powszechnie w internetowych tekstach krajoznawczych - przykłady z tej grupy przytoczę $\mathrm{w}$ analizie - A.S.);

2) teksty oficjalne i urzędowe: wyzwaniem dla tłumacza są w nich przede wszystkim tytuły, stanowiska, wszelkie honorifica, patronimiki, czyli personalia; autorka zauważa większą tendencję w języku rosyjskim do używania pełnych (z wbudowanymi hiperonimami) nazw geograficznych; w tekstach rosyjskich folderów turystycznych daje się zauważyć uniwerbizacja modelu (Балтика, Адриатика);

3) teksty artystyczne (literackie) - tu szczególnie podkreśla autorka istnienie uświęconych tradycją odpowiedników; sądzę, że warto do tego dodać kwestię onimów znaczących, które w kontekście literackim, z uwzględnieniem intertekstualności, rządzą się własnymi prawami (na ten temat zob. także poniżej p. 9);

4) teksty w języku obiegowym - obfitują w zdrobnienia, nazwy skrócone miast funkcjonujące lokalnie (dodam, że w wielu tekstach typu 1, szczególnie skierowanych do młodszych odbiorców, pojawiają się dość często te ostatnie - A.S.);

5) teksty naukowe i techniczne - interesujące ze względu na antroponimy, bądź to użyte bezpośrednio, bądź to w obrębie terminów czy nomenów (tu szczególnie daje znać o sobie tradycja, która bywa odmienna w przypadku rosyjskiego i polskiego: do przykładu autorki silnik Diesla - дизельный мотор dodałabym również przypadek regular-

${ }^{1}$ Zob. E. Padučeva, Wypowiedź i jej odniesienie do rzeczywistości, Warszawa 1992 (tłum. Zofia Kozłowska) - to jeden z nielicznych przykładów, kiedy nazwisko autorki zostało zapisane (również na okładce książki) za pomocą transliteracji ze znakami diakrytycznymi.

${ }^{2}$ W swoich rozważaniach na temat ewaluacji przekładu i normy Barbara Z. Kielar podkreśla, że ocena powinna być każdorazowo odniesiona do konkretnego układu translacyjnego (zob. Kielar 2003: 125). 
nych zmian formy językowej, rosyjski przymiotnik relacyjny vs. polska konstrukcja przyimkowa o znaczeniu lokatywno-charakteryzująсут tурu Эразм Роттердамский - Erazm z Rotterdamu - A.S.);

6) popularnonaukowe - dużo nazw peryfrastycznych, przymiotników odimiennych (darwinowska teoria ewolucji);

7) teksty literatury podróżniczej i pamiętnikarskiej (personalia z zasobów międzynarodowych, trudno rozpoznawalne ze względu na różnice adaptacyjne);

8) teksty historyczne - pełne onimów oznaczających postaci historyczne, bitwy, miejscowości, przymiotniki od etnonimów, nazwy dynastii (niekiedy bardzo odmienne modele), imiona królewskie ${ }^{3}$. (Warto dodać, że historyzmy pojawiają się nierzadko w tekstach krajoznawczo-turystycznych, w których nie brak przy okazji odniesień do współczesności ${ }^{4}$ - A.S.);

9) teksty science fiction - pełne nazewnictwa wymyślonego, nierzadko znaczącego, które zdaniem autorki wymaga rozwiązań o ciekawym dla czytelnika, w miarę możności bliskim oryginałowi brzmieniu, uwzględniającym bagaż konotacji kulturowych i wewnętrzną formę onimów. W moim przekonaniu dotyczy to obecnie w największym stopniu ogromnie popularnej literatury fantasy ${ }^{5}$.

Powyższa klasyfikacja mogłaby zostać uzupełniona o teksty z pogranicza literatury, np. eseistyczne, zawierające nazwy „tekstów kultury” (na przykład unikatowych obiektów architektonicznych, tytuły dzieł malarskich, mu-

${ }^{3}$ W tej ostatniej kwestii szczególnie wyraźnie widać siłę tradycji - imiona królewskie są zruszczone (np. Людовик - Лyu) oraz spolszczone (Ludwik - Louis). Ciekawy przykład odstępstwa od tradycji rozważa Hejwowski (2004: 69), ponadto wszyscy chyba przywykliśmy do doniesień prasowych i agencyjnych, w których król Hiszpanii to Juan Carlos (a nie Jan Karol, jak nakazywałaby tradycja), za to najczęściej pojawia się z małżonką Zofią (sic!).

${ }^{4}$ Jeżeli w rysie historycznym opisu Suzdala pojawia się nieistniejąca dziś formacja Ruś Suzdalsko-Włodzimierska, to z racji nawiązań tekstowych oczywiste wydaje się, że nazwa miasta obwodowego powinna zostać podana raczej w postaci Włodzimierz niż Władimir). Uderza też odmienność w tradycyjnym doborze hiperonimów: w wielu przypadkach księstwom w tekstach polskich odpowiadają w rosyjskim wyspecjalizowane ekwiwalenty гериогство, грабство (np. Księstwo Durham - графство Дарем) - A.S.

${ }^{5}$ Bardzo ciekawe przykłady rozwiązań translatorskich i szczególnych trudności można znaleźć w rosyjskich tłumaczeniach powieści Andrzeja Sapkowskiego. Niekiedy trudno ustalić, do jakiej tradycji nawiązuje imię bohatera i jak w związku z tym należałoby je wymawiać. Bez rozstrzygnięcia tego dylematu tłumacz nie może zastosować odpowiedniej transkrypcji. Pod moim kierunkiem powstała w 2010 r. praca licencjacka Bereniki Lato pt. Особенности перевода имен собственных в литературе фэнтези: на материале русских переводов избранных рассказов Анджея Сапковского. 
zycznych). Powstały już nawet prace ${ }^{6}$ na temat „artionimów” - jednak raczej ukierunkowane językoznawczo i kulturowo, w obrębie jednego języka, nie zaś konfrontacji przekładowej, a ta ma swoje szczególne prawa i zasady.

Kulpina proponuje również inne podziały (2009: 283-284). Departamentyzacja onomastykonu jest wyodrębnieniem specyficznych typów imion ze względu na trudności przekładowe dla języka polskiego i rosyjskiego:

1) przekład jednostek onomastykonu prymarnego (szukanie jedynego ekwiwalentu, rzadkie przypadki synonimii onomastycznej - w analizie poniżej odpowiada temu przypadek Гданьский залив/Гданьская бyxma - to równorzędne z punktu widzenia frekwencyjności w tekstach fachowych i popularnych odpowiedniki nazwy Zatoka Gdańska),

2) przekład jednostek onomastykonu wtórnego (określenia peryfrastyczne - o ile przytoczona przez autorkę nazwa Северная Венеция - Wenecja Pótnocy jest czytelna dla polskiego odbiorcy, to już Северная Пальмира - Palmira Pótnocy nie wywołuje u przeciętnego czytelnika szczególnych skojarzeń, jeśli nie sięgnie on chociażby do Słownika wyrazów obcych i zwrotów obcojęzycznych W. Kopalińskiego),

3) przekład choronimów standardowych (Lubelszczyzna - Люблинский край), mniej standardowych (Приамурье - Przyamurze, przykł. własny - A.S.) i niestandardowych (Pótnoc - dla Polaka to Skandynawia, dla Rosjanina - Arktyka).

Na początkowym etapie kursu tłumaczenia bądź propedeutyki tłumaczenia warto stopniować trudności, zaczynając od nazw odnoszących się do grupy 1.

Kolejna klasyfikacja - regionalizacja i parametryzacja (Kulpina 2009: 285-289), jest podziałem dokonanym na podstawie przynależności onimów do regionów pochodzenia. $\mathrm{W}$ ich obrębie podkreśla się niezgodności i rozbieżności międzyjęzykowe (w tym również korelacje i prawidłowości):

1) przekład jednostek onomastycznych języka polskiego na rosyjski,

2) przekład jednostek onomastycznych języka rosyjskiego na polski,

3) elementy $z$ języków trzecich (przeważnie internacjonalizmy).

Nas interesują w tym kontekście grupy 2 (w kolejności) oraz 1.

Podziały wewnętrzne:

- W grupie 2 trudności dotyczą właściwej adaptacji fonologicznej i morfologicznej na gruncie polszczyzny (dodam w kontekście dydaktycznym -

${ }^{6}$ Е.А. Бурмистрова, 2006, Названия произведений искусства как объект ономастики. Автореферат диссертации на соискание ученой степени кандидата филологических наук, Волгоград, tekst dostępny pod adresem: http://planeta-imen.narod.ru/novosti/avtoreferat.html (tekst do pobrania $\mathrm{w}$ formacie skompresowanym zip pod nazwiskiem autorki). 
również ortograficznej, zwłaszcza pisownia wielką literą). Poza uwzględnieniem tradycji fonetyczno-fonologicznych, różnic rodzajowych i trudno wytłumaczalnych czy w ogóle niewyjaśnionych rozbieżności (za Kulpiną: Петербург - Peters $b u r g$ ) warto pokazać na przykładach przypadki chwiejności transkrypcji, jej zmienności oraz zaburzenia ogólnego obrazu wynikającego $\mathrm{z}$ istnienia jednostek utrwalonych tradycją, a także tendencji globalizacyjnych;

- W grupie 1 Kulpina wymienia przede wszystkim konieczność dostosowania do warstwy fonetyczno-fonologicznej i morfologicznej języka docelowego - rosyjskiego, zwracając uwagę na tradycyjne odpowiedniki grup głoskowych (odwołuje się do zasady transkrypcji praktycznej według Jermołowicz), na problem końcówek z -ó- (Краков jako wyjątek) i -ń (różnice rodzajowe), a także na nazwy dwuczłonowe (Желязова-Воля obok Желязовая Воля - przykład A.S.).

Uwzględniając omówione wyżej typologie i klasyfikacje, przyjrzyjmy się zatem wybranym przykładom w tekstach, które mogą stanowić materiał do analizy, a w przypadku tłumaczeń - „bazę danych” jako teksty paralelne i analogiczne.

\title{
1. Onimy rosyjskie w tekstach polskich - analiza wybranych przykładów
}

1.1. Jubileusz 200. rocznicy urodzin Chopina dostarcza nam znakomitych materiałów do analizy $\mathrm{z}$ interesującego nas punktu widzenia, ponieważ w bardzo wielu koncertach biorą udział wybitni wykonawcy rosyjscy, a w programach ich występów obecna jest muzyka wielkich Rosjan, kompozytorów muzyki klasycznej. To nieuchronnie prowokuje zderzenie tradycji z dniem dzisiejszym, zasad dawnych i nowych. Jak radzą sobie z tą sprzecznością autorzy tekstów, plakatów, programów umieszczanych na stronach internetowych filharmonii?

\author{
Koncert Symfoniczny \\ Międzynarodowy Festiwal Muzyczny Chopin i jego Europa \\ Wykonawcy: \\ Nikolai Lugansky - fortepian \\ Russian National Orchestra \\ Mikhail Pletnev - dyrygent
}


W programie:

Sergey Rachmaninov - Wariacje na temat Paganiniego

Fryderyk Chopin - Koncert fortepianowy e-moll op. 11

Organizator: Narodowy Instytut Fryderyka Chopina

[http://obchody.chopin2010.pl/pl/kalendarium/lista-wydarzen/ wydarzenia-nadchodzace.html?tx_cal_controller[view]=event\&tx_cal_controller[type]=tx_cal_phpicalendar\&tx_cal_controller[uid]=3172\&tx_cal_controller[lastview]=view-list|page_id-109|offset52\&tx_cal_controller[year] $=2010 \& t x \_c a l \_c o n t r o l l e r[m o n t h]=08 \& t x$ cal_controller $[$ day $]=15 \& c H a s h=$ de1784c0c95bdda28d186201c0dbd713 (dostęp: 15 marca 2010 r.)]

Wyróżnione antroponimy zostały oddane w tekście polskim w sposób niewątpliwie ujednolicony i konsekwentny. Od razu widać, że nie jest to transkrypcja ani też transliteracja zgodna z polską normą. Z czego wynika uzus (bo zjawisko to jest coraz bardziej powszechne) stanowiący odstępstwo od normy?

Młodzi ludzie mówią żartobliwie, że jeśli nie ma cię w Google, to nie żyjesz. Zapis nazwisk wykonawców jest zgodny z formą najczęściej spotykaną w sieci, w przestrzeni językowej świata Zachodu (Nikolai to zapis francuski, Lugansky - angielski, więc też nie do końca ujednolicony...). W takiej postaci zobaczymy je na płytach wydanych przez zachodnie firmy fonograficzne. Jest wielce prawdopodobne, że muzycy życzą sobie, by na afiszach ich nazwiska widniały w powszechnie znanej formie. Jednakże wątpliwości budzi zapis nazwiska i imienia kompozytora.

Stajemy przed trudnym wyborem: albo jednolitość zasad zapisu, albo odniesienie każdego onimu do odpowiedniej grupy - odpowiedniki uznane funkcjonują w każdym języku (tu: polskim) od wielu lat (nawet stuleci) i zasadniczo nie powinno się ich ignorować, jednak oczywistą konsekwencją hołdowania tradycji będzie tu niehomogeniczność formalna.

Sergei [Sergey] Vasilievich [Vasilyevich] Rachmaninov [Rachmaninoff] [Russian: Сергей Васильевич Рахманинов, Sergej Vasil'evič Rakhmaninov] (http://www.bach-cantatas.com/Bio/Rachmaninov-Sergei.htm - strona w języku angielskim, dostęp: 15 marca 2010 r.)

Tyle możliwych wariantów transferu możemy odnaleźć na stronach i w tekstach anglojęzycznych.

$\mathrm{Z}$ odpowiednikami uznanymi w języku polskim też bywa różnie. Spotykamy się z wariantywnością zapisu: 
RACHMANINOW Siergiej Wasiliewicz, ur. 1 IV 1873 w Siemionowie k. Nowogrodu, zm. 28 III 1943 w Beverly Hills (Kalifornia), ros. pianista i kompozytor [...] (http://www.rmfclassic.pl/muzyka/encyklopedia,element,1579928.html, dostęp: 15 marca 2010 r.)

Rachmaninow Siergiej Wasiljewicz, ur. 1 IV 1873, Siemionowo koło Nowogrodu Wielkiego, zm. 28 III 1943, Los Angeles, rosyjski kompozytor i pianista; od 1918 w USA [...] (elektroniczna wersja encyklopedii PWN, http:// encyklopedia.pwn.pl/haslo.php?id=3965148, dostęp: 15 marca 2010 r.)

1893 - Sergiusz W. Rachmaninow - Aleko - rosyjska (lista oper, dramatów muzycznych, musicali - elektroniczna wersja encyklopedii PWN - http:// encyklopedia.pwn.pl/haslo.php?id=714049, dostęp: 15 marca 2010 r.)

Jak widać, nawet w obrębie tego samego tekstu (fakt, że jest to makrotekst, bo tak należałoby traktować wielotomową encyklopedię) brak całkowitej jednolitości - mamy do czynienia z transkrypcją, jednak w ostatnim przypadku ze spolszczonym imieniem.

Jeszcze jeden przykład, w którym powtarza się przytoczone już nazwisko wykonawcy:

Michaił Pletniew - pianista, dyrygent, kompozytor. O dyrygowaniu mówi, że to nie zawód, ale przywilej, a sens ma tylko wtedy, gdy maestro wie o dziele więcej niż muzycy orkiestry. Ale tym razem sprawa dotyczy pierwszego z muzycznych wcieleń Pletniewa. Niewątpliwie najciekawsza pianistyczna osobowość średniego pokolenia, obok Krystiana Zimermana oczywiście. [...]

Jowita Dziedzic-Golec, RMF Classic

Beethoven: Piano Concertos Nos. 1 \& 3

Mikhail Pletnev

Russian National Orchestra

Christian Ganach

Deutsche Grammophon

Tekst pochodzi ze strony internetowej radia RMF Classic ${ }^{7}$. Widzimy obok siebie dwie różne postaci tego samego onimu, jednak przesłanki są jasne: pierwszy tekst ma charakter opisowy, informacyjny, zwraca się bezpośrednio do słuchacza/czytelnika - stąd transkrypcja. Drugi natomiast pochodzi z okładki płyty wydanej przez Deutsche Grammophon, prezentowanej

\footnotetext{
${ }^{7}$ http://www.rmfclassic.pl (dostęp: 15 marca 2010 r.).
} 
w audycji autorskiej Jowity Dziedzic-Golec - dlatego widzimy zastosowanie transliteracji międzynarodowej.

Co warto uświadomić przyszłym adeptom translatorskiego rzemiosła (sztuki?)? Po pierwsze, że jednolitość zastosowanych rozwiązań nie zawsze idzie w parze z zasadami: spójny obraz zaburzają przypadki odpowiedników tradycyjnych. Po drugie, że typ funkcjonalny tekstu i przewidywany adresat determinują $\mathrm{w}$ największym stopniu wybór techniki. To są przypadki względnej niemożności, jednakże nie błędu. Te niedobre rozwiązania $\mathrm{z}$ racji szczupłości miejsca pominę, wspomnę tylko, że w edycjach DVD klasyki kina rosyjskiego (jak i na plakatach filmowych) można znaleźć wiele rażących uchybien ${ }^{8}$ wobec normy i reguł zwyczajowych, wynikających prawdopodobnie z pośpiechu i niedbałości.

1.2. Teksty o tematyce krajoznawczej, zarówno te encyklopedyczne, jak i użytkowe (foldery turystyczne, oferty biur podróży, strony domowe miast), zawierają wiele toponimów, w tym mikrotoponimów o znacznym stopniu nacechowania kulturowego. Również one, podobnie jak personalia, stanowią wyzwanie dla tłumaczy i autorów tekstów. Na zasady obowiązujące w przypadku antroponimów nakłada się bowiem ogólna filozofia, czyli strategia przybliżenia obcej rzeczywistości czytelnikowi docelowemu, zanurzonemu w innej kulturze i realiach.

W tekstach o charakterze poznawczym zazwyczaj dominuje model zorientowany na odbiorcę, co przejawia się w stosowaniu technik adaptujących („naturalizujących” czy też „udomowiających”). W tekstach przewodników, które mają za zadanie doprowadzenie odbiorcy do określonego miejsca, stosowane są zazwyczaj techniki zorientowane na kulturę wyjściową („egzotyzujące"), które pozwalają zachować oryginalny koloryt i brzmienie (jak najdosłowniej). Tym bardziej ważne jest trzymanie się jednego modelu (strategii), co nie zawsze jest możliwe - znów - z powodu istnienia tzw. ekwiwalentów uznanych oraz ciągle zachodzących zmian na polskich mapach świata9

Dodatkową komplikacją jest obecność onimów (głównie mikrotoponimów) znaczących, wielu tłumaczy ulega bowiem pokusie kalkowania nazwy czy też zastosowania metody eksplikacji semantycznej ${ }^{10}$.

${ }^{8}$ http://www.rmfclassic.pl (dostęp: 15 marca 2010 r.).

9 Na przykład na okładce płyty DVD wydanej przez dystrybutora „Kino Świat” w cyklu „Wielkie filmy, wielcy reżyserzy” wśród wykonawców mamy nazwiska: Nikita Michałkow - zgodnie z transkrypcją (i tradycją), a obok - Nadezhda Michałkowa - imię zapisane „po nowemu” (lub $\mathrm{w}$ transliteracji), natomiast nazwisko jak poprzednio. Takiej niekonsekwencji można uniknąć.

${ }^{10}$ „W ciągu lat, które upłynęły od tego czasu zmieniały się zasady, którymi obecna Komisja 
Ławra Troicko-Siergijewska (hasło: Siergijew Posad, elektroniczna wersja encyklopedii PWN, http://encyklopedia.pwn.pl/haslo.php?id=3975035, dostęp: 15 marca 2010 r.)

\section{Ławra Troicko-Siergijewska}

(dla klasztoru w miejscowości Siergijew Posad w obwodzie moskiewskim w Rosji; zmiany wprowadzone na XXIX posiedzeniu Komisji, 13 grudnia 2006 roku, nazwy dodane - http://www.gugik.gov.pl/komisja/nazew_pol_ zm_2006-12-13.php, a także: http://www.gugik.gov.pl/komisja/pliki/zmiany_egzonimow_wg_krajow.pdf, s. 75, dostęp: 15 marca 2010 r.)

Ławra Troicko-Siergiejewska; Troice-Siergijewa ławra (trb.), Troice-Sergieva lavra (trl.)

(Nazewnictwo geograficzne świata, z. 11. Europa, cz. I, Warszawa 2009, publikacja Komisji Standaryzacji Nazw Geograficznych poza Granicami Rzeczypospolitej Polskiej przy Głównym Geodecie Kraju, Główny urząd Geodezji i Kartografii, s. 184, http://www.gugik.gov.pl/komisja/pliki/zeszyty/ zeszyt_11.pdf, , dostęp: 15 marca 2010 r.)

Ławra Troice-Siergijewa (Lewicki 2002)

W przytoczonych dwu pierwszych przykładach widać jednolitą zasadę transfer na poziomie morfologicznym (dostosowanie do schematów słowotwórczych języka polskiego, jeśli chodzi o przymiotniki relacyjne). Niepokoi przykład trzeci, sugerujący, iż nazwa pochodzi od imienia Сергеŭ, a nie Сергuй (onim pochodzi z tego samego źródła, tyle że z innej broszury KSNG). Przykład ostatni odzwierciedla zasadę zachowania kolorytu wyjściowego i jest właściwie transkrypcją onimu pierwotnego.

Standaryzacji Nazw Geograficznych kieruje się przy ustalaniu zalecanego nazewnictwa. Chodzi przede wszystkim o poprawność stosowania egzonimów. Początkowo zalecano ich szerokie używanie, a nawet spolszczanie tych nazw, które w Polsce znane nie były. Później okazywano znacznie większą w tym względzie ostrożność. Problem jest jednak bardzo złożony, budzi kontrowersje i zrozumiałe spory. Komisja stara się nie usuwać tych nazw, które w polskim języku są utrwalone i które stanowią część naszego dziedzictwa kulturowego. Jednocześnie niektóre z takich nazw jako $\mathrm{w}$ praktyce niestosowane są jednak przez Komisję niezalecane. Chodzi więc $\mathrm{z}$ jednej strony o to, aby chronić te polskie nazwy, które na ochronę zasługują - a z drugiej strony pozbywać się tych, które wprowadzono pochopnie lub które wyszły z użycia. Jednocześnie niektóre dawniej używane nazwy zastępowane są nowszymi. Opinie, a zatem i podejmowane w tych sprawach decyzje, mogą być, i istotnie były, bardzo dyskusyjne.

Rozwiązania przyjęte przez Komisję, w skład której wchodzi liczne grono specjalistów: geografów, historyków, językoznawców, kartografów, wynikają często z gorących dyskusji i nie są pozbawione subiektywizmu. Kryteria ustalania nazw nie mogą być bowiem jednoznaczne - tym bardziej, że język jest żywy i zmienne są nasze doświadczenia. Dlatego każda zmiana polskiego egzonimu jest dyskutowana i w przypadku każdej takiej nazwy podejmowana jest indywidualna decyzja” - wyróżnienia moje - A.S., http://www.gugik.gov.pl/komisja/ (dostęp: 15 marca 2010 r.). 
SUZDAL, m. w środk. Części Rosji, w obwodzie władymirskim, nad Kamienką [...], $26 \mathrm{~km}$ od Władymira [...]. Zabytki [...].

Monastyry: Pokrowski z soborem Pokrowskim (1514) z galerią arkadową, wolno stojącą dzwonnicą i Świętymi Wrotami z nadbramną cerkwią Błagowieszczenija (1516), a także cerkiew Poczęcia Anny z dzwonnicą i refektarzem (XVI w.); Rizpołożeński z soborem Rizpołożeńskim [...], Spaso-Jewfimijewski z cerkwią Błagowieszczenija i dzwonnicą $[\ldots]^{11}$.

Wyróżnione mikrotoponimy (nazwy obiektów sakralnych) w przytoczonym fragmencie są efektem zastosowania w jednym tekście różnych technik: transkrypcji z retuszem morfologiczno-ortograficznym (większość obiektów) oraz eksplikacji semantycznej (cerkiew Poczęcia Anny). Ta niekonsekwencja była do uniknięcia. Inną kwestią jest zastosowanie nietradycyjnej nazwy miasta obwodowego i - konsekwentnie - takiego derywatu (Władymir, władymirski - transkrypcja z modyfikacją fonetyczną zamiast uznanego ekwiwalentu Włodzimierz, włodzimierski ${ }^{12}$ ).

Transfer nazw obiektów sakralnych jest bardzo ciekawym problemem, zasługującym na odrębne badanie ${ }^{13}$, tu jednak ograniczę się wyłącznie do powyższego przykładu.

\section{Onimy polskie w tekstach rosyjskich - analiza wybranych przykładów}

2.1. O Romanie Polańskim z wielu powodów, artystycznych i pozaartystycznych, było głośno w ostatnim czasie, jednak w świadomości wielu Rosjan (i w wielu tekstach rosyjskich) jego nazwisko istnieje od dawna - tyle że w różnych wersjach.

ПОЛЯ'НСКИЙ Роман (Поланский; Roman Polański) (p. 18 августа 1933, Париж), польский кинорежиссер. (http://www.megabook.ru/ArticlePrint.asp?AID=663382, dostęp: 15 marca 2010 r.)

\footnotetext{
${ }^{11} \mathrm{Na}$ ten temat zob. Hejwowski 2004: 91-93 oraz 99-104.

${ }_{12}$ Nowa encyklopedia powszechna PWN, t. 6, Warszawa1997, s. 127-128.

${ }^{13}$ W elektronicznej wersji Encyklopedii PWN na pierwszym miejscu znajduje się odpowiednik uznany.
} 
Полнометражный кинодебют «Нож в воде», снятый в 1962, принес Роману Полански мировую известность. (http://www.kinomag.ru/author-auz1708.html, dostęp: 15 marca 2010 r.)

W przykładzie pierwszym widzimy jeden z najbardziej tradycyjnych wariantów zapisu - transkrypcja praktyczna z modyfikacją morfologiczną, pozwalającą dostosować onim do paradygmatu przymiotnikowego $\mathrm{w}$ języku rosyjskim. Nie ma jasności co do przekazania połączenia głosek -la- - w zasadzie powinno to być - $л я-$, jednakże $\mathrm{w}$ wymowie być może bliższa oryginałowi jest wersja z -ла-. Przykład drugi natomiast pokazuje nowszą tendencję: nazwisko zostało przetranskrybowane, jednak bez retuszu morfologicznego, co czyni je nieodmiennym. Wynika to być może stąd, że Polański, mieszkający i tworzący od lat na Zachodzie, nie jest już postrzegany przez pryzmat swoich związków z Polską, a raczej jako Amerykanin w Paryżu - na to wskazywałaby nieodmienność nazwiska.

Wydawałoby się, że trudno spodziewać się niespodzianek w przypadku postaci tak utrwalonej w kulturze światowej jak Fryderyk Chopin (Szopen?). Jednak i tu nie ma jedności, przynajmniej w kwestii imienia.

В 2010 году будет отмечаться 200-летие со дня рождения композитора Фридерика Шопена. В Польше продолжается подготовка мероприятий «Года Фридерика Шопена». [...] (http://www.muzcentrum.ru/ news/2009/07/item2116.html, dostęp: 15 marca 2010 r.)

Сегодня можно и подивиться тому, сколь велика была тяга нижегородца-петербуржца Милия Алексеевича Балакирева (в этом году 100 лет со дня его кончины) к творчеству и личности Фредерика Франчишека Шопена из Желязовой Воли близ Варшавы, где 200 лет назад, 1 марта 1810 года - по другим данным неделей раньше - он явился свету и миру. [...] РИА Новости, 09:33 01/03/2010

Pierwsza wersja zapisu imienia jest niewątpliwie transkrypcją imienia polskiego, druga - francuskiego. Frekwencja obu jest porównywalna, przy czym pierwsza dominuje w tekstach chronologicznie starszych.

2.2. Jeśli chodzi o toponimy, to jak widać choćby na przykładzie prac W. Kulpinej, jest to zagadnienie bardzo bogate i wielowątkowe. Przytoczone poniżej krótkie przykłady ilustrują rozwiązania podyktowane wymiarem funkcjonalnym tekstu. Są w nich obecne także elementy znaczące oraz toponim niestandardowy. 
Гданьск - крупный морской порт Польши. Расположен он на берегу Гданьского залива у южных берегов Балтики. [...]

Обязательно прогуляйтесь по Королевскому тракту Гданьска. Начинается он у комплекса городских ворот, в который входят Зеленые ворота, Злодейские ворота и Золотые ворота, далее тракт идёт по Длинной улице и заканчивается на площади Длинный Рынок. (http://www. svali.ru/catalog/100000/12150/index.htm, dostęp: 15 marca 2010 r.)

Улица Длуги Тарг и Главная ратуша

Гданьская бухта (польск. Zatoka Gdańska), залив Балтийского моря у берегов СССР и Польши. [...] (http://gatchina3000.ru/great-sovietencyclopedia/bse/008/934.htm, dostęp: 15 marca 2010 r.)

Самые достопримечательные памятники сосредоточены в районе Королевского пути - улиц Длуга и Длуги Тарг, вдоль которых расположились богато украшенные каменные дома и исторические архитектурные сооружения. (http:/gorod.polska.ru/miasta/gdans.php, dostęp: 15 marca 2010 r.)

Гданьск (Gdańsk), город и порт в Польше, близ впадения Вислы в Балтийское м., на берегу Гданьской бухты. Г. вместе с гг. Гдыня и Сопот, связанными друг с другом автострадой, образует городскую агломерацию, т. н. Труймясто (Трёхградье). Ю. В. Илинич.

(http://dic.academic.ru/dic.nsf/bse/77978/\%D0\%93\%D0\%B4\%D0B0\%D0\%BD\%D1\%8C\%D1\%81\%D0\%BA, dostęp: 15 marca 2010 r.)

Przytoczone przykłady pokazują odpowiedniki będące synonimami (Гданьская бухта - Гданьский залив) oraz toponim niestandardowy (Труймясто - Трёхградье). Co ciekawe, w ostatnim przypadku Wielki słownik rosyjsko-polski (2004) podaje tylko drugą z tych nazw (Tpëxгpadse), która jest kalką na poziomie słowotwórczym i eksplikacją semantyczną zarazem. Kolejność w haśle dużej encyklopedii (Больщая советская энциклопедия) jest nieprzypadkowa - od nazwy obco brzmiącej (podanej w transkrypcji) do eksplikującej formę wewnętrzną i właściwe znaczenie onimu.

Bardziej problematyczny jest przykład nazw ulic. W jednej z przytoczonych wyżej wersji autor tekstu uległ pokusie i przetłumaczył elementy znacząсе (Длинная улица, Длинный Рьнок). Nie jest to najszczęśliwsze rozwiązanie, bo poza walorem poznawczym (?) nie ma swojego wymiaru funkcjonalnego, a w każdym razie go zatraca.

Niestety, problem mikrotoponimów w tłumaczeniu nie doczekał się jeszcze wyczerpującego i systematycznego opisu, co wynika może stąd, że absolutnie jednoznaczne rekomendacje nie są możliwe. Autorzy monografii (choć- 
by wielokrotnie tu cytowany Jermołowicz) nie poświęcają temu zagadnieniu wiele uwagi, koncentrując się na innych problemach tłumaczeniowych.

\section{Wnioski}

Implikacje dydaktyczne (wstęp do zajęć warsztatowych z tłumaczeń pisemnych)

1. Na wstępie uświadomienie konsekwencji bariery alfabetu, zapoznanie z podstawowymi technikami transferu na poziomie grafii (transliteracja) i fonii (transkrypcja) zgodnymi z polską normą (kierunek tłumaczenia: rosyjski $\rightarrow$ polski), wychwycenie elementów niejednoznacznych czy arbitralnych (transkrypcja: rosyjskie $e, \ddot{e}, ю, я$ po głoskach sonornych, odstępstwa od normy związane $\mathrm{z}$ tradycją, $\mathrm{tj}$. odpowiedniki uznane). Istotne są przy tym kwestie ortograficzne, rozbieżności pomiędzy zasadami w języku rosyjskim i polskim (wielkie litery). W dalszej kolejności - to samo zagadnienie w kierunku przeciwnym: zapoznanie $\mathrm{z}$ normami oraz uzusem w przypadku tekstów rosyjskich, traktujących o rzeczywistości polskiej („trzecia kultura” odpowiednio później).

2. Prezentacja (do analizy) fragmentów tekstów, najlepiej niebędących tłumaczeniami, w których zostały zastosowane różnorodne techniki transfe$\mathrm{ru}$ - w celu wywnioskowania, jaki jest sugerowany zakres użycia owych technik, gdzie na regułę dążenia do konsekwencji i jednolitości nakłada się zasada zachowania odpowiedników uznanych, która kreuje sytuację niemożności (lecz w żadnym wypadku nie jest to poziom błędu). Sugerowana kolejność: teksty polskie o realiach rosyjskich, następnie odwrotnie, na końcu „trzecia kultura" w tekstach rosyjskich.

3. Odwołanie się do autorytatywnych publikacji, w tym do opracowań leksykograficznych, encyklopedycznych oraz do źródeł, które mają charakter zdecydowanie preskryptywny (broszury oraz na bieżąco publikowane protokoły posiedzeń komisji, wprowadzające zmiany w obrębie egzonimów - portal KSNG, wybrane słowniki i encyklopedie). W odniesieniu do tekstów rosyjskich - wybrane słowniki i encyklopedie, wydawnictwa poprawnościowe, opracowania kartograficzne.

4. Analiza „protokołu rozbieżności” pomiędzy autorytetami, uświadomienie sobie mechanizmów oraz zastosowanych rozwiązań translatorskich, powodujących te różnice. Świadomość ta pomaga dokonać wyboru pomiędzy formami poprawnymi, ale odpowiadającymi różnym projektom translatorskim, zdeterminowanym wymiarem pragmatycznym i funkcjonalnym 
tekstu, który ewentualnie będzie tłumaczony (ten wymiar z racji dydaktycznych może być narzucony przez nauczyciela).

5. Prezentacja przykładów tekstów, w których na zastosowane techniki (transkrypcja, transliteracja) nakłada się znak czasu - ewolucja form zapisu wynikająca ze zmian przepisów (w szczególności regulacji prawnych - np. rozporządzeń dotyczących zapisu antroponimów w paszportach), przemian cywilizacyjnych, procesów globalizacyjnych, różnic w postrzeganiu określonego wycinka rzeczywistości (będzie to dotyczyło głównie personaliów).

6. Analiza przypadków nieuniknionej (poziom niemożności) i możliwej do wyeliminowania, niepożądanej (poziom błędu, a co najmniej uchybienia wobec normy) niejednorodności zastosowanych metod w obrębie jednego tekstu. Warto zadać studentom ćwiczenie polegające na przeredagowaniu opublikowanego już tekstu ze względu na kryterium nazw własnych, tak aby zachować maksymalną jednolitość rozwiązań.

Tak skomponowany program być może pozwoli uniknąć nadużywanego przez uczących się argumentu „przecież znalazłem(-am) taki zapis w Internecie”, co jest zmorą chyba każdego wykładowcy.

\section{Literatura}

Giliariewskij, R.S., Starostin, B.A., 1985, - Гиляревский, P.С., Старостин, Б.А., 1985, Иностраннве имена и названия в русском тексте. Справочник, Москва.

Grzenia, J., 2003, Słownik nazw własnych, Warszawa.

Grzenia, J., 2008, Słownik nazw geograficznych $z$ odmiana i wyrazami pochodnymi, Warszawa.

Hejwowski, K., 2004, Kognitywno-komunikacyjna teoria przekładu, Warszawa. Hejwowski, K., Szczęsny A., Topczewska U. (red.), 2009, 50 lat polskiej translatoryki, Warszawa.

Jermołowicz, D.I., 2005, - Ермолович, Д.И., 2005, Имена собственные: теория и практика межвязыковой передачи, Москва.

Kielar, B.Z., 2003, Zarys translatoryki, Warszawa.

Kulpina, W., 2009, „Właściwości konfrontacji przekładowej onomasticonu polskiego i rosyjskiego", [w:] 50 lat polskiej translatoryki, K. Hejwowski, A. Szczęsny, U. Topczewska (red.), Warszawa, s. 283-295.

Lewicki, R., 2002, Христианство. Русско-польский словарь, Chrześcijaństwo. Słownik rosyjsko-polski, Warszawa. 
Lewicki, R., 2008, Polsko-rosyjski słownik nazw własnych, Lublin.

Nowy słownik ortograficzny PWN z zasadami pisowni i interpunkcji, 2002,

E. Polański (red.), Warszawa, zasady transliteracji oraz transkrypcji dostępne także pod adresami: http://so.pwn.pl/zasady.php?id=629696 oraz http://so.pwn.pl/zasady.php?id=629697 (dostęp: 3 kwietnia 2010 r.).

Wielki słownik polsko-rosyjski PWN, 2005, opracowanie zbiorowe, J. Wawrzyńczyk (red.), Warszawa.

Wielki słownik rosyjsko-polski PWN, 2004, opracowanie zbiorowe, J. Wawrzyńczyk (red.), Warszawa.

Приложение N 6 к Инструкции о порядке оформления и выдачи паспортов гражданам Российской Федерации, http://base.garant.ru/11900742. htm (dostęp: 3 kwietnia 2010 r.).

Приказ МВД РФ от 12 февраля 2009 г. N 128 «О внесении изменений в приказ МВД России от 26 мая 1997 г. $N$ 310», http://base.garant. ru/11900742.htm (dostęp: 3 kwietnia 2010 r.).

Приложение N 7 к Инструкиии о порядке оформления и выдачи паспортов гражданам Российской Федераиии для выезда из Российской Федераиии и въезда в Российскую Федераиию, http://base.garant. ru/11900742.htm (dostęp: 3 kwietnia 2010 r.).

http://www.gugik.gov.pl/komisja/ksng.php - strona główna Komisji Standaryzacji Nazw Geograficznych poza Granicami Polski przy Głównym Geodecie Kraju (dostęp: 3 kwietnia 2010 r.).

http://www.gugik.gov.pl/komisja/posiedzenia.php - protokoły posiedzeń w porządku chronologicznym (dostęp: 15 marca 2010 r.).

http://www.gugik.gov.pl/komisja/wydawnictwa.php - zeszyty (w formacie PDF, do pobrania) poświęcone poszczególnym częściom świata (dostęp: 15 marca 2010 r.).

http://www.gugik.gov.pl/komisja/nazwy_pol.php - broszura (w formacie PDF, do pobrania) - zmiany w polskim nazewnictwie geograficznym (dostęp: 15 marca 2010 r.).

http://www.gugik.gov.pl/komisja/pliki/zmiany_egzonimow_wg_krajow.pdf - broszura (w formacie PDF, do pobrania) - zmiany w polskim nazewnictwie świata (dostęp: 15 marca 2010 r.). 


\section{Embarras de choix - proper names as an eternal problem in translation teaching Between the norm and the usage (on the example of Polish and Russian texts) Summary}

The paper focuses on proper names and, more specifically, personal names, toponyms and microtoponyms with a high degree of cultural embeddedness. The author draws on the classification of translation rules and methods (techniques) developed by Ermolovich, with a special focus on difficult cases of transfer where transliteration and transcription are employed. Two directions of translation are discussed: Polish into Russian and Russian into Polish.

The paper analyses discrepancies between linguistic norms and usage, where problems originate from the existence of recognised equivalents, arbitrariness of transcription and globalisation (widespread use of the Internet). In the face of these challenges, consistency in a translation project is difficult to retain.

The author proposes a set of practical exercises that can be used during translation classes (drawing on the analysis of original texts) in order to make beginner translation students aware of the existing problems and potential solutions. Examples of Polish realia in Russian texts and Russian realia in Polish texts are presented. 


\section{Aneks 1}

\begin{tabular}{|c|c|}
\hline $\begin{array}{c}\text { Zasada zachowania formy } \\
\text { graficznej }\end{array}$ & $\begin{array}{l}\text { Metoda transferu graficznego } \\
\text { (bez zmian) }\end{array}$ \\
\hline $\begin{array}{c}\text { Zasada podobieństwa } \\
\text { graficznego }\end{array}$ & Metoda transliteracji \\
\hline Zasada podobieństwa fonicznego & $\begin{array}{l}\text { Metoda tanskrypcji (allofonicznej } \\
\text { fonematycznej, praktycznej) }\end{array}$ \\
\hline $\begin{array}{l}\text { Zasada odzwierciedlenia } \\
\text { (kolorytu narodowego) onimu }\end{array}$ & Metoda hybrydowa \\
\hline $\begin{array}{l}\text { Zasada zachowania jedności } \\
\text { (tożsamości) onimu }\end{array}$ & Metoda eufoniczna \\
\hline Zasada eufonii & $\begin{array}{l}\text { Metoda modyfikacji gramatycznej } \\
\text { (głównie morfologicznej) }\end{array}$ \\
\hline $\begin{array}{c}\text { Zasada adaptacji do systemu } \\
\text { gramatycznego języka } \\
\text { docelowego }\end{array}$ & $\begin{array}{l}\text { Metoda ograniczenia } \\
\text { wariantywności nazwy własnej }\end{array}$ \\
\hline $\begin{array}{c}\text { Zasada zachowania tradycji } \\
\text { historycznej }\end{array}$ & Metoda eksplikacji semantycznej \\
\hline $\begin{array}{l}\text { Zasada oddania znaczenia (treści } \\
\text { pojęcia) onimu }\end{array}$ & $\begin{array}{c}\text { Metoda wykorzystania } \\
\text { tradycyjnego (uznanego) } \\
\text { nazewnictwa }\end{array}$ \\
\hline $\begin{array}{c}\text { Zasada wykorzystania zasobów } \\
\text { onimicznych } \\
\text { języka docelowego }\end{array}$ & Metoda deonimizacji \\
\hline $\begin{array}{c}\text { Zasada uwzględnienia formy } \\
\text { wewnętrznej (motywacji) onimu }\end{array}$ & Metoda zastąpienia/zamiany onimu \\
\hline & Metoda transpozycji \\
\hline & Metoda kalki \\
\hline & $\begin{array}{l}\text { Metoda analogii funkcjonalnej } \\
\text { (zamiana formy wewnętrznej) }\end{array}$ \\
\hline
\end{tabular}

Związki pomiędzy zasadami a metodami tworzenia odpowiedników - Jermołowicz 2005: 167, adaptacja moja - A.S. 


\section{Aneks 2}

1. W rozporządzeniu Ministerstwa Spraw Wewnętrznych Federacji Rosyjskiej nr 310 z dnia 26 maja 1997 r. (obecnie utraciło ono moc prawną) znajduje się załącznik nr 6 do instrukcji dotyczącej wzorów i trybu wydawania paszportów obywatelom Federacji Rosyjskiej. Sformułowano tu m.in. zasady transferu imion i nazwisk rosyjskich za pomocą transliteracji francuskiej:
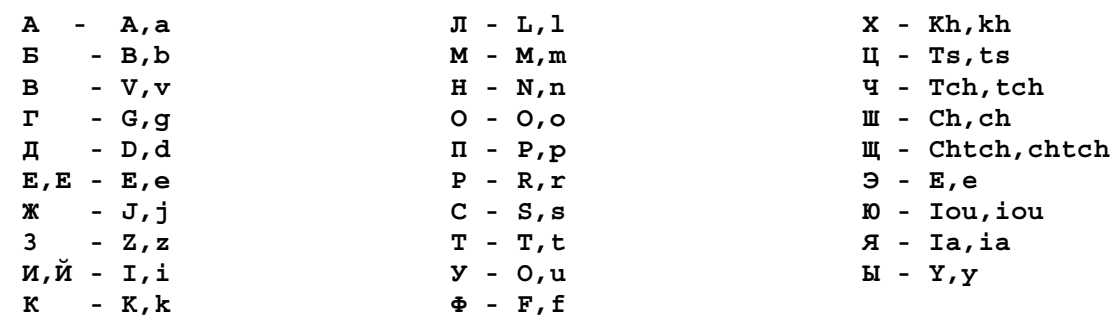

G, $g$ przed $e, i, y$ zapisujemy wraz z $u$ (gue, gui, guy): Гирев - Guirev. $C$ - pomiędzy dwiema samogłoskami jak ss: Гусев - Goussev. Nazwiska zakończone na uн piszemy z e niemym: Васин - Vassine. Jeżeli $e$ występuje po znaku miękkim, to zapisujemy ie: Васильeв - Vassiliev. Połączenie spółgłosek $\kappa с$ zapisujemy jako $x$ : Максимов - Махіmov, Александp-Alexandr

(W oryginalnym dokumencie jest: Масимов - Maxsimov, Александр Alexsandr - jak widać, nawet w instrukcji są nieścisłości, wystarczy spojrzeć na listę imion (Alexandre) i staje się oczywiste, że $s$ jest niepotrzebne!).

2. W rozporządzeniu Ministerstwa Spraw Wewnętrznych Federacji Rosyjskiej nr 128 z dnia 12 lutego 2009 r. - o zmianach do rozporządzenia MSW FR nr 310 z dnia 26 maja 1997 r. znajduje się załącznik nr 7 do instrukcji dotyczącej wzorów i trybu wydawania paszportów obywatelom Federacji Rosyjskiej. Sformułowano tu m.in. zasady transferu imion i nazwisk rosyjskich za pomocą transliteracji angielskiej:

Samogłoski $a, e, \ddot{e}, u, o, y, b l, \ni, ю, я$ zastępowane są odpowiednio przez $a, e$ lub też ye (po znaku miękkim, np. Vasilyev), i, o, $u, y, e, y u, y a$ (oryginalna tabela poniżej). 
(cc) (i) $\fallingdotseq$ 